\title{
Ganglioside-magnetosome complex formation enhances uptake of gangliosides by cells
}

This article was published in the following Dove Press journal:

International Journal of Nanomedicine

6 November 2015

Number of times this article has been viewed

\author{
Feng Guan' \\ Xiang $\mathrm{Li}^{\prime}$ \\ Jia Guo' \\ Ganglong Yang' \\ Xiang $\mathrm{Li}^{2}$ \\ 'The Key Laboratory of Carbohydrate \\ Chemistry and Biotechnology, \\ Ministry of Education, School of \\ Biotechnology, ${ }^{2}$ Wuxi Medical School, \\ Jiangnan University, Wuxi, People's \\ Republic of China
}

\begin{abstract}
Bacterial magnetosomes, because of their nano-scale size, have a large surface-tovolume ratio and are able to carry large quantities of bioactive substances such as enzymes, antibodies, and genes. Gangliosides, a family of sialic acid-containing glycosphingolipids, function as distinctive cell surface markers and as specific determinants in cellular recognition and cell-to-cell communication. Exogenously added gangliosides are often used to study biological functions, transport mechanisms, and metabolism of their endogenous counterparts. Absorption of gangliosides into cells is typically limited by their tendency to aggregate into micelles in aqueous media. We describe here a simple strategy to remove proteins from the magnetosome membrane by sodium dodecyl sulfate treatment, and efficiently immobilize a ganglioside $\left(\mathrm{GM}_{1}\right.$ or $\left.\mathrm{GM}_{3}\right)$ on the magnetosome by mild ultrasonic treatment. The maximum of $11.7 \pm 1.2 \mu \mathrm{g} \mathrm{GM}_{1}$ and 11.6 $\pm 1.5 \mu \mathrm{g} \mathrm{GM}_{3}$ was loaded onto $1 \mathrm{mg}$ magnetosome, respectively. Complexes of ganglioside-magnetosomes stored at $4{ }^{\circ} \mathrm{C}$ for certain days presented the consistent stability. The use of $\mathrm{GM}_{1}$-magnetosome complex resulted in the greatest enhancement of ganglioside incorporation by cells. $\mathrm{GM}_{3}$-magnetosome complex significantly inhibited EGFinduced phosphorylation of the epidermal growth factor receptor. Both of these effects were further enhanced by the presence of a magnetic field.
\end{abstract}

Keywords: bacterial magnetosome, nanoparticle, cellular uptake, ganglioside, inhibition

\section{Introduction}

Magnetic $\mathrm{Fe}_{3} \mathrm{O}_{4}$ nanoparticles, termed magnetosomes, are synthesized by Magnetospirillum magneticum and related bacteria. ${ }^{1}$ Magnetosome chains are enclosed by a lipid bilayer membrane with high content of transmembrane proteins. ${ }^{2}$ Because of their high magnetization, monodispersity, and range of size $(\sim 35-120 \mathrm{~nm})$, magnetosomes have many potential applications in biomedical diagnostics and nanoscience fields, notably the delivery of targeted drugs and genes and detection of pathogens. ${ }^{3,4}$ Their degradability and biocompatibility with a variety of cell types and structures make magnetosomes useful in many in vitro and in vivo applications. ${ }^{5,6}$

Glycosphingolipids, characteristic components of mammalian cell membranes, are involved in cell growth, adhesion, migration, and many other processes. ${ }^{7,8}$ Gangliosides, a family of glycosphingolipids that contain one or more sialic acids, are distinctive surface markers and often function as specific determinants in cellular recognition and cell-to-cell communication. Ganglioside $\mathrm{GM}_{3}$ affects receptor-associated tyrosine kinases of many cellular factors, including epidermal growth factor receptor (EGFR), platelet-derived growth factor, fibroblast growth factor, neuronal growth factor, and insulin..$^{9-11}$ Ganglioside $\mathrm{GM}_{1}$, a major component of total ganglioside mixtures from mammalian brains, has been applied for therapy of a variety of neurological disorders. ${ }^{12}$ Exogenously applied $\mathrm{GM}_{1}$ promotes neurite outgrowth following neural injury in several animal models. ${ }^{13,14}$ Nanocapsulized, chemically modified gangliosides have
Correspondence: Xiang Li

Wuxi Medical School, Jiangnan University, 1800 Lihu Avenue, Wuxi, Jiangsu 214122, People's Republic of China

Tel +8651085918126

Fax +86 51085918126

Email xiangli@jiangnan.edu.cn (c) (1) (5) 2015 Guan et al. This work is published by Dove Medical Press Limited, and licensed under Creative Commons Attribution - Non Commercial (unported, v3.0) License. The full terms of the License are available at http://creativecommons.org/licenses/by-nc/3.0/. Non-commercial uses of the work are permitted without any further Dove Medical Press Limited, provided the work is properly attributed. Permissions beyond the scope of the License are administered by Dove Medical Press Limited. Information on how to request permission may be found at: http://www.dovepress.com/permissions.php 


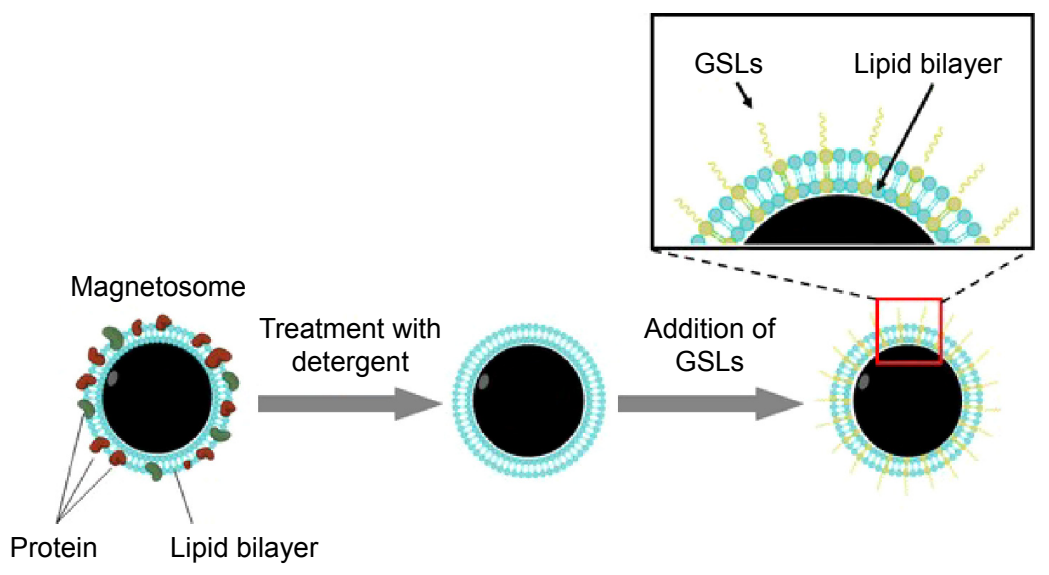

Figure I Technique (schematic) for synthesis of ganglioside-magnetosome complex. Abbreviation: GSLs, Glycosphingolipids.

been developed and incorporated into various polymers or liposomes to improve delivery efficiency, increase blood circulation time, or stimulate immune responses. ${ }^{15-17}$ The primary obstacle to the administration of gangliosides to cells is their tendency to aggregate into micelles in aqueous media. In studies by Orlando et $\mathrm{al}^{18}$ and Ghidoni et al ${ }^{19}$, only $1 \%-3 \%$ of administered $\mathrm{GM}_{1}$ actually entered brain cells in mouse and rat models. ${ }^{18,19}$

We developed a novel strategy using bacterial magnetosomes to enhance cellular uptake of gangliosides. Magnetosomes were isolated and purified from Magnetospirillum gryphiswaldense,${ }^{20}$ proteins and lipopolysaccharides were removed from their membranes by sodium dodecyl sulfate (SDS) treatment, and specific gangliosides were grafted onto the modified magnetosome by mild ultrasonic treatment (Figure 1).

\section{Materials and methods}

\section{Cell lines and culture}

Human epidermoid carcinoma cell line A431 and human mammary epithelial cell line MCF-10A were obtained from Cell Bank of the Chinese Academy of Sciences (Shanghai, People's Republic of China). A431 and MCF-10A cells were cultured in Dulbecco's Modified Eagle's Medium containing $10 \%$ fetal bovine serum (FBS), $100 \mathrm{IU} / \mathrm{mL}$ penicillin, and $100 \mu \mathrm{g} / \mathrm{mL}$ streptomycin at $37^{\circ} \mathrm{C}$ in a $5 \% \mathrm{CO}_{2}$ atmosphere. Human highly malignant, invasive bladder cancer cell line YTS-1 was a kind gift from Dr Sen-itiroh Hakomori (The Biomembrane Institute, Seattle, WA, USA). YTS-1 cells were cultured in RPMI 1640 medium supplemented with $10 \%$ FBS (Hyclone, Logan, UT, USA) and 1\% penicillin/streptomycin at $37^{\circ} \mathrm{C}$ in a $5 \% \mathrm{CO}_{2}$ atmosphere. As only cell lines were used in this study, no ethics approval was required.

\section{Bacterial strain, gangliosides}

Magnetospirillum gryphiswaldense strain MSR-1 (DSM6361) was a kind gift from Prof Ying Li (China Agricultural University, Beijing, People's Republic of China). Gangliosides $\mathrm{GM}_{1}$ and $\mathrm{GM}_{3}$ were from Matreya LLC (Pleasant Gap, PA, USA).

\section{Preparation of magnetosomes}

MSR-1 cells were cultured as described previously ${ }^{20}$ and collected by centrifugation at $8,000 \times g$ for 10 minutes at room temperature (RT). An aliquot ( $\sim \mathrm{g}$ wet weight) was resuspended in $10 \mathrm{~mL}$ of $10 \mathrm{mM}$ phosphate-buffered saline (PBS; pH 7.4) and disrupted by two passes through a French press (ATS Engineering Inc., Brampton, ON, Canada) at 1,000 psi. Magnetosomes were collected using neodymiumiron-boron (Nd-Fe-B) magnets and washed 8-10× with PBS in a mild ultrasonic bath (50 W; TY92-II; Xinyi, Ningbo, People's Republic of China). Purified magnetosomes were lyophilized for 20 hours and stored at $-20^{\circ} \mathrm{C}$.

\section{Preparation of ganglioside-magnetosomes}

A $1 \mathrm{mg}$ magnetosome sample was boiled with 1\% SDS for 5 minutes to remove membrane proteins. The modified magnetosomes were isolated using a Nd-Fe-B magnet, washed $3 \times$ with $1 \mathrm{~mL}$ of $10 \mathrm{mM}$ PBS (pH 7.4), and resuspended in $1 \mathrm{~mL}$ of $20 \mu \mathrm{g} / \mathrm{mL} \mathrm{GM}_{3}$ solution in $10 \mathrm{mM}$ PBS. The mixture was washed in an ultrasonic bath $(100 \mathrm{~W})$ for 10 minutes at $4{ }^{\circ} \mathrm{C}$ and then incubated for 2 hours at RT. Resulting $\mathrm{GM}_{3}$-magnetosomes were washed with $10 \mathrm{mM}$ PBS. $\mathrm{GM}_{3}$ concentration before and after reaction with magnetosomes was determined by high-performance thin layer chromatography (HPTLC). GM -magnetosomes and control phosphatidylethanolamine-magnetosomes were prepared in a 
similar manner. Ganglioside-magnetosome complex was stored at $4^{\circ} \mathrm{C}$, and sterilized by UV irradiation prior to experiments.

\section{High-performance thin layer chromatography}

Lipids were extracted from magnetosomes as described previously. ${ }^{21}$ In brief, a $2 \mathrm{mg}$ magnetosome sample was suspended in $950 \mathrm{~mL}$ chloroform-methanol solution (chloroform/methanol/distilled water 1:2:0.8), incubated for 2 hours, and lipid and non-lipid fractions were separated using a Nd-Fe-B magnet. The same volume of chloroformmethanol solution was used to extract equivalent amounts

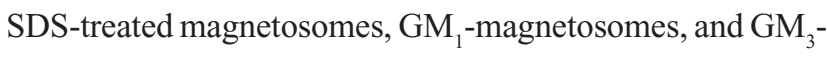
magnetosomes. Purified lipid fractions were subjected to HPTLC (silica gel 60 plates; Merck, Whitehouse Station, NJ, USA) with chloroform/methanol/water (65:35:4, v/v/v) as developing solvent, and visualized using iodine.

\section{Transmission electron microscopy}

Magnetosome samples were applied to carbon-coated 150mesh copper grids (Nisshin EM Co., Tokyo, Japan) and dried at RT. Transmission electron microscopy (TEM) samples were prepared by drying a drop of solution in a dark room on amorphous carbon-coated nickel grids. Magnetosome size and morphology were observed by TEM (model H700-H; Hitachi, Tokyo, Japan).

\section{Fourier-transform infrared spectroscopy}

Samples were dispersed in distilled water. Dry particles were mixed with ground $\mathrm{KBr}$ crystals, and samples were pressed as pellets. Spectra were acquired using a Nicolet Nexus670 iS10 Fourier-transform infrared spectroscopy (Thermo Fisher Scientific, San Jose, CA, USA).

\section{Protein capture by $\mathrm{GM}_{3}$-magnetosomes}

$\mathrm{GM}_{3}$-magnetosomes $(1 \mathrm{mg})$ were mixed with $1 \mathrm{~mL}$ A431 cell protein lysate $(1 \mathrm{mg} / \mathrm{mL})$, incubated overnight at $4^{\circ} \mathrm{C}$, and washed $3 \times$ with Tris-buffered saline $(+)(130 \mathrm{mM}$ $\mathrm{NaCl} / 10 \mathrm{mM}$ Tris- $\mathrm{HCl}$ ( $\mathrm{pH} 8.0$ ) containing $0.9 \mathrm{mM} \mathrm{CaCl}_{2}$, $0.5 \mathrm{mM} \mathrm{MgSO}_{4}$, and $0.1 \mathrm{mM} \mathrm{MnCl}_{2}$ ). Protein bound to $\mathrm{GM}_{3}-$ magnetosomes was solubilized by boiling in $50 \mu \mathrm{L}$ SDS/ polyacrylamide gel electrophoresis (PAGE) sample buffer for 5 minutes, and analyzed by Western blotting.

\section{Western blotting}

$\mathrm{GM}_{3}$-magnetosomes were incubated with A431 cell lysate as above, mixed with boiling $1 \%$ SDS solution, and proteins interacting with the magnetosomes were extracted. Each extracted protein sample $(30 \mathrm{~mL})$ was mixed with SDS sample buffer (final concentration: $62.5 \mathrm{mM}$ Tris- $\mathrm{HCl}$, pH 6.8, 5\% 2-mercaptoethanol, 2\% SDS, 5\% sucrose, $0.002 \%$ bromophenol blue), denatured, and subjected SDS-PAGE on $7.5 \%(\mathrm{w} / \mathrm{v})$ polyacrylamide gel. Protein was transferred onto a polyvinylidene fluoride membrane and blotted with anti-EGFR antibody (dilution 1:1,000; Cell Signaling Technology, Beverly, MA, USA) and goat anti-rabbit antibody (dilution 1:5,000; Cell Signaling Technology). Signals were detected with a ChemiDoc XRS + system (Bio-Rad, Hercules, CA, USA).

\section{Effect of $\mathrm{GM}_{3}$ on EGF-induced tyrosine phosphorylation of EGFR}

A431 cells $\left(1 \times 10^{5}\right.$ per well $)$ were cultured in 12 -well plates in Dulbecco's Modified Eagle's Medium containing 10\% FBS at $37^{\circ} \mathrm{C}$ until $\sim 80 \%$ confluence. Cells were starved for 12 hours, incubated with $\mathrm{GM}_{3}$ or $\mathrm{GM}_{3}$-magnetosomes with/ without magnetic field for 2 hours, stimulated with EGF for 5 minutes, washed in ice-cold PBS, and lysed in $100 \mu \mathrm{L}$ lysis buffer. Protein in the supernatant (equal amount for each sample) was subjected to SDS-PAGE (7\% gel) and Western blotting with primary anti-phosphorylated EGFR (pEGFR; dilution 1:1,000; Cell Signaling Technology) or anti-EGFR (dilution 1:1,000) antibody and horseradish peroxidase-conjugated anti-rabbit secondary antibody. Immunoreactive proteins were visualized using an ECL Kit (PA112-02; Tiangen, Beijing, People's Republic of China).

\section{Confocal laser scanning microscopy}

YTS-1 cells $\left(1 \times 10^{4}\right.$ per well in 24 -well plates $)$ were cultured on sterilized coverslips (diameter $12 \mathrm{~mm}$; Fisherbrand, San Jose, CA, USA) in RPMI 1640 until 70\% confluence, then cultured for 24 hours with PBS, GM 1 plus magnetosomes (10 $\mu \mathrm{g} / \mathrm{mL}), \mathrm{GM}_{1}$-magnetosome complex (10 $\mu \mathrm{g} / \mathrm{mL})$, or $\mathrm{GM}_{1}$-magnetosome complex $(10 \mu \mathrm{g} / \mathrm{mL})$ under magnetic field, fixed with $4 \%$ fresh paraformaldehyde for 20 minutes, washed $3 \times$ with PBS, blocked with $5 \%$ bovine serum albumin in PBS (w/v) at RT for 2 hours, incubated with $0.4 \mu \mathrm{g} / \mathrm{mL}$ Fluorescein isothiocyanate (FITC)-labeled cholera toxin B subunit (CTB; specifically recognizes $\mathrm{GM}_{1}$; Sigma-Aldrich Co., St Louis, MO, USA), rinsed with PBS to remove excess dye, and stained with DAPI $(5 \mu \mathrm{g} / \mathrm{mL})$ in PBS for 30 minutes. Coverslips were mounted with Glycergel (DakoCytomation, Carpinteria, CA, USA) and observed by laser confocal fluorescence microscopy (model Eclipse Ti-U; Nikon, Tokyo, Japan). 


\section{Flow cytometry}

YTS- 1 cells $\left(1 \times 10^{5}\right.$ per well $)$ were cultured in 12 -well plates in RPMI 1640 until 70\% confluence, then cultured for 24 hours in fresh medium supplemented with PBS, $\mathrm{GM}_{1}(1 \mu \mathrm{g} / \mathrm{mL})$ plus magnetosomes $(10 \mu \mathrm{g} / \mathrm{mL}), \mathrm{GM}_{1}$ magnetosome complex (concentration of total complex added to medium $=10 \mu \mathrm{g} / \mathrm{mL}$; amount of $\mathrm{GM}_{1}$ per $1 \mathrm{mg}$ magnetosome $=0.104 \mu \mathrm{g}$ ), or $\mathrm{GM}_{1}$-magnetosome complex under magnetic field, digested with trypsin, washed with PBS, blocked with 5\% bovine serum albumin/PBS for 1 hour, stained with FITC-labeled CTB for 1 hour at RT, and analyzed by flow cytometry (model Accuri C6; Becton Dickinson, Franklin Lakes, NJ, USA).

\section{Statistical analysis}

The data were analyzed by $t$-test using Prism 5 program. Differences in results were considered significant when $P$-value was $\leq 0.05$.

\section{Results}

\section{Characterization of ganglioside- magnetosome complexes}

Removal of the proteins from the magnetosome membrane by SDS treatment is the first step to generate the gangliosidemagnetosome complexes. The released protein from magnetosome after SDS treatment was examined by the bicinchoninic acid method (Figure 2A). The highest concentration of released protein in the supernatant was reached in 5 minutes after SDS treatment. The membranes of SDS-treated and -untreated magnetosomes were then characterized by Fourier-transform infrared spectroscopy. SDS-treated magnetosomes showed lower signals of amide I at $1,656 \mathrm{~cm}^{-1}$ (from $\mathrm{C}=\mathrm{O}$ stretching vibration), amide II at $1,537 \mathrm{~cm}^{-1}$ (from $\mathrm{N}-\mathrm{H}$ bending vibration and $\mathrm{C}-\mathrm{N}$ stretching vibration), and $\mathrm{NH}$ bending vibration at 3,282 $\mathrm{cm}^{-1}$ (Figure 2B). ${ }^{22}$ These findings indicate that most proteins on the magnetosomes were removed successfully.

Protein removal by SDS treatment created more space on the magnetosome lipid membrane. The lipids were partially disrupted by SDS treatment (Figure 2Ci, lanes 1, 2). Incubation of gangliosides with magnetosomes in an ultrasonic bath resulted in insertion of ceramides (the hydrophobic portion of gangliosides) into the lipidic core of the membrane. Gangliosides inserted into the membrane were clearly detectable by HPTLC (Figure 2Ci, lanes 3, 4). After storage at $4^{\circ} \mathrm{C}$ for $2,4,6$, or 8 days, gangliosides on the gangliosidemagnetosome complexes were extracted and clearly shown on a thin layer chromatography plate by HPTLC analysis (Figure 2Cii and Ciii). TEM micrographs revealed that the membranes were made thinner or partially eliminated by the SDS treatment, but were restored by incubation with $\mathrm{GM}_{1}$ or $\mathrm{GM}_{3}$ (Figure 2D). The zeta potential of GM1-magnetosome complexes and GM3-magnetosome complexes were -17.84 and -14.84 , respectively, and that obtained from magnetosomes was -42.18 (Table S1). Typical particle sizes of magnetosomes are $\sim 30 \mathrm{~nm}$, whilst the size of gangliosidemagnetosome reached at 150-200 $\mathrm{nm}$ (Figure S1). These findings suggest that gangliosides were stably inserted into the outer membrane layer through lipid-lipid interaction.

We next investigated the binding capacity of gangliosides on magnetosomes. The binding capacity of coupled $\mathrm{GM}_{1}$ or $\mathrm{GM}_{3}$ on magnetosomes was maximal at 30 minutes incubation in an ultrasonic bath, whereas incubation for longer periods induced $\mathrm{GM}_{1}$ or $\mathrm{GM}_{3}$ degradation (Table S2), consistent with a previous report. ${ }^{23}$ Maximal loading capacity of gangliosides was $11.7 \pm 1.2 \mu \mathrm{g}$ per $1 \mathrm{mg}$ magnetosome for $\mathrm{GM}_{1}$, and $11.6 \pm 1.5 \mu \mathrm{g}$ per $1 \mathrm{mg}$ magnetosome for $\mathrm{GM}_{3}$. The same ganglioside load was observed in both 50 and $100 \mu \mathrm{g}$ gangliosides, indicating that the magnetosome loading capacity was saturated. We therefore used $50 \mu \mathrm{g}$ gangliosides and $1 \mathrm{mg}$ magnetosomes for reparation of gangliosidemagnetosome complexes in subsequent experiments. The magnetosomes and ganglioside-magnetosome complex were sterilized by ultrafiltration for following toxicity assay. Magnetosomes and the sterilized ganglioside-magnetosome complex showed no obvious toxic effect on cell growth (Figure S2A-C), consistent with previous studies. ${ }^{4}$

\section{Uptake of GM,-magnetosome complex by YTS-I cells}

Our working hypothesis was that the uptake of ganglioside into cells is promoted by the use of ganglioside-magnetosome complex to enhance ganglioside solubility and distribution. With bladder cancer cell line YTS-1 (low GM 1 expressor) ${ }^{24}$ as a model, we measured the cell surface expression of $\mathrm{GM}_{1}$ based on binding to CTB. ${ }^{25}$ The incubation of YTS- 1 cells with $\mathrm{GM}_{1}$-magnetosome complex significantly enhanced the fluorescence signal of FITC-labeled CTB for $\mathrm{GM}_{1}$ (Figure 3B), observed under laser confocal fluorescence microscopy. Cellular uptake of $\mathrm{GM}_{1}$-magnetosome complex was much higher under magnetic field (Figure 3A, B). The lower level of FITC signal for $\mathrm{GM}_{1}$ in YTS-1 cells was determined by flow cytometric analysis, whereas cellular uptake of $\mathrm{GM}_{1}$ contributed by $\mathrm{GM}_{1}$-magnetosome complex was significantly increased. And the magnetic field was able to further promote the uptake of $\mathrm{GM}_{1}$-magnetosome complex (Figure 3C). Notably, the fluorescence signal showed that a portion of GM 
A

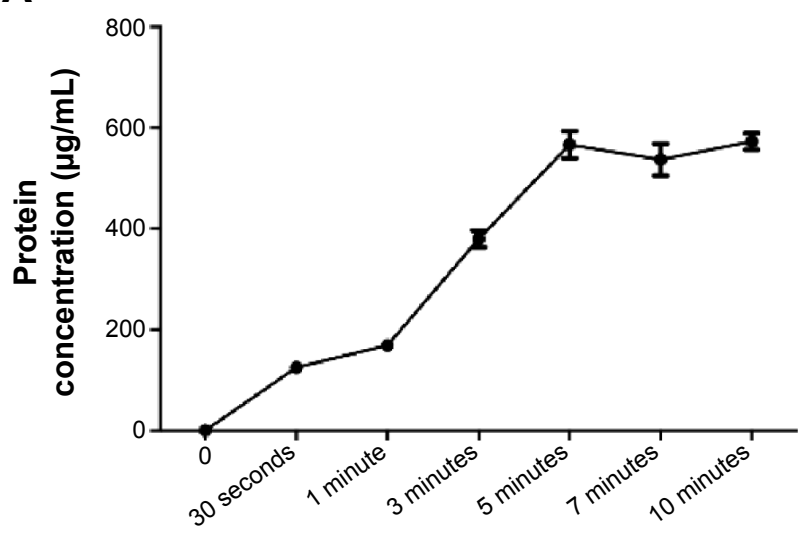

B

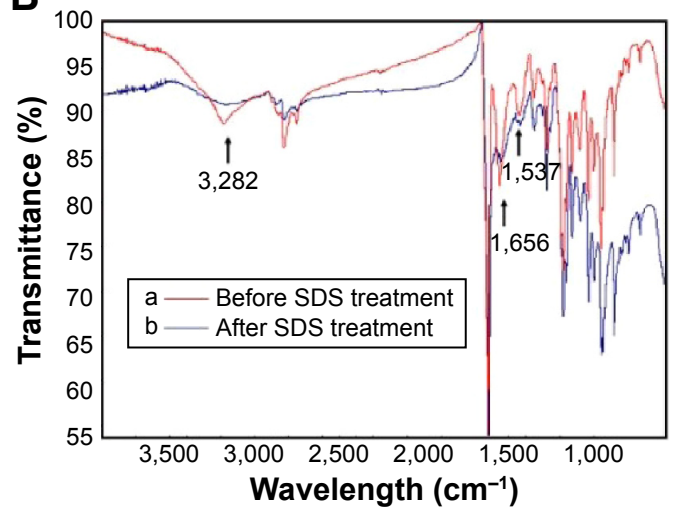

C

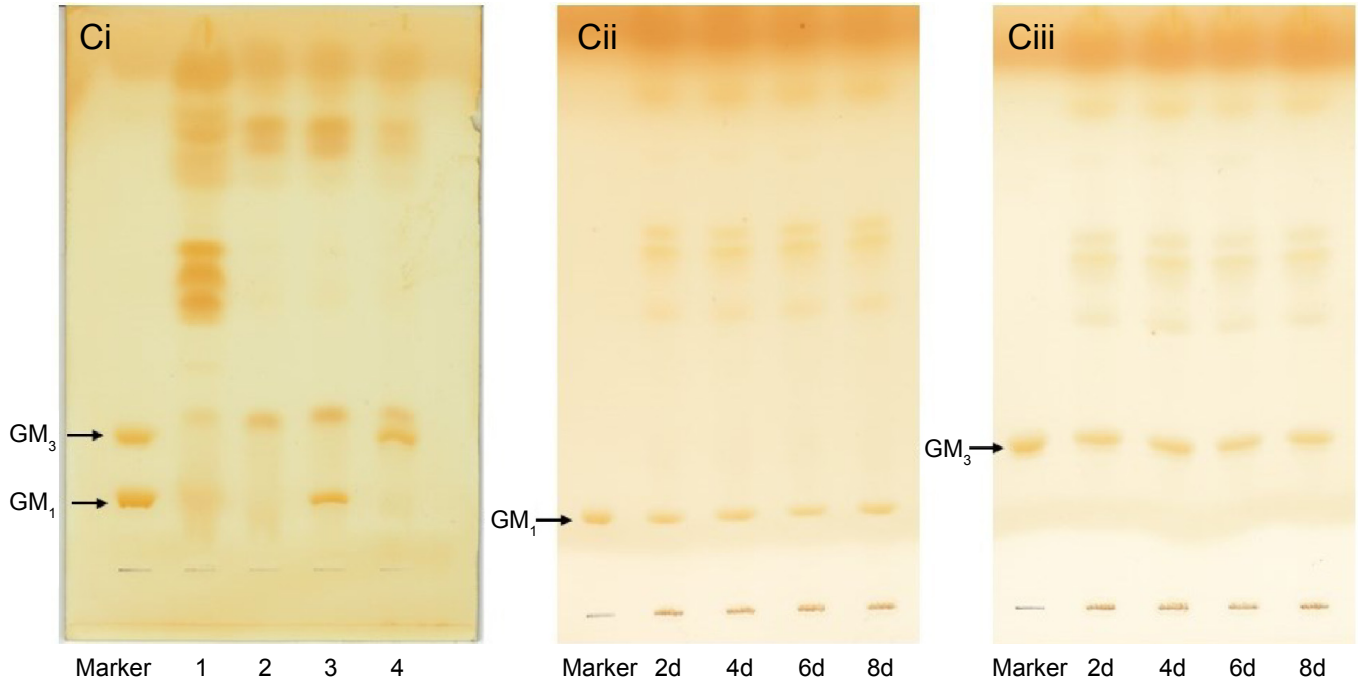

D
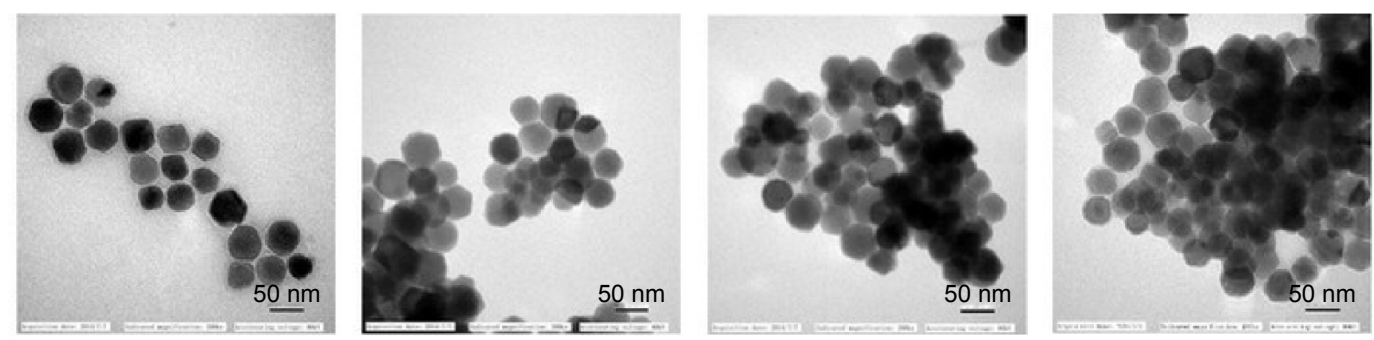

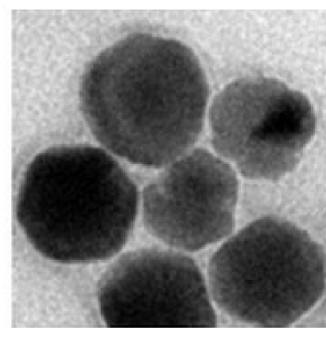

Magnetosome

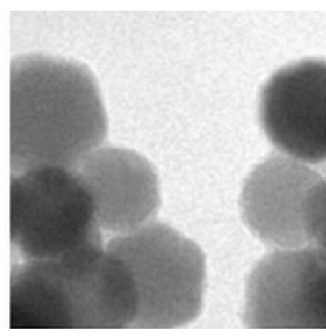

Magnetosome treated with SDS

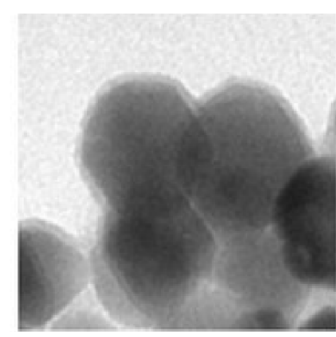

$\mathrm{GM}_{1}$-magnetosome complex

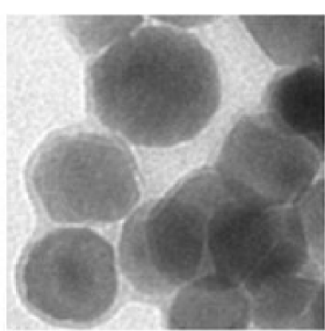

$\mathrm{GM}_{3}$-magnetosome complex

Figure 2 Characteristics of ganglioside-magnetosome complex.

Notes: (A) The protein released from magnetosome with SDS treatment for 30 seconds, I, 3, 5, 7 and 10 minutes was determined by BCA assay. (B) FT-IR spectra of magnetosomes before and after SDS treatment. (Ci) Equivalent amounts of control magnetosomes (lane I), SDS-treated magnetosomes (lane 2), GM 1 -magnetosomes (lane 3), and GM -magnetosomes (lane 4) were extracted, subjected to HPTLC, and visualized as described in M\&M/"high-performance thin layer chromatography". Equivalent amounts of $\mathrm{GM}_{1}$-magnetosomes (Cii) or $\mathrm{GM}_{3}$-magnetosomes (Ciii) stored at $4^{\circ} \mathrm{C}$ for 2 (shown as $2 \mathrm{~d}$ ), 4 (4d), 6 (6d), and 8 (8d) days were extracted, subjected to HPTLC, and visualized as described in M\&M/“high-performance thin layer chromatography". (D) TEM imaging of four types of magnetosomes as in (B). UPper row: $200,000 \times$ magnification. Scale bar $=50 \mathrm{~nm}$. Lower row: close-ups of images in upper row.

Abbreviations: BCA, bicinchoninic acid; FT-IR, Fourier-transform infrared spectroscopy; HPTLC, high-performance thin layer chromatography; M\&M, materials and methods; SDS, sodium dodecyl sulfate; TEM, transmission electron microscopy. 
A
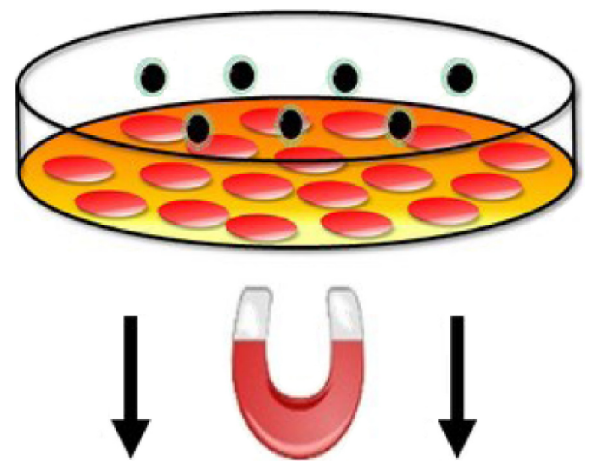

B PBS

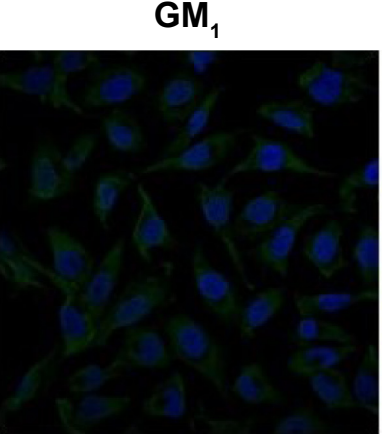

$\mathrm{GM}_{1}$ + magnetosome

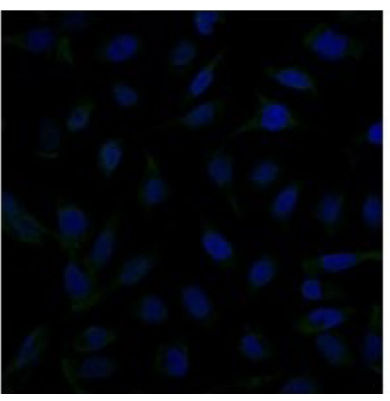

$\mathrm{GM}_{1}$-magnetosome complex
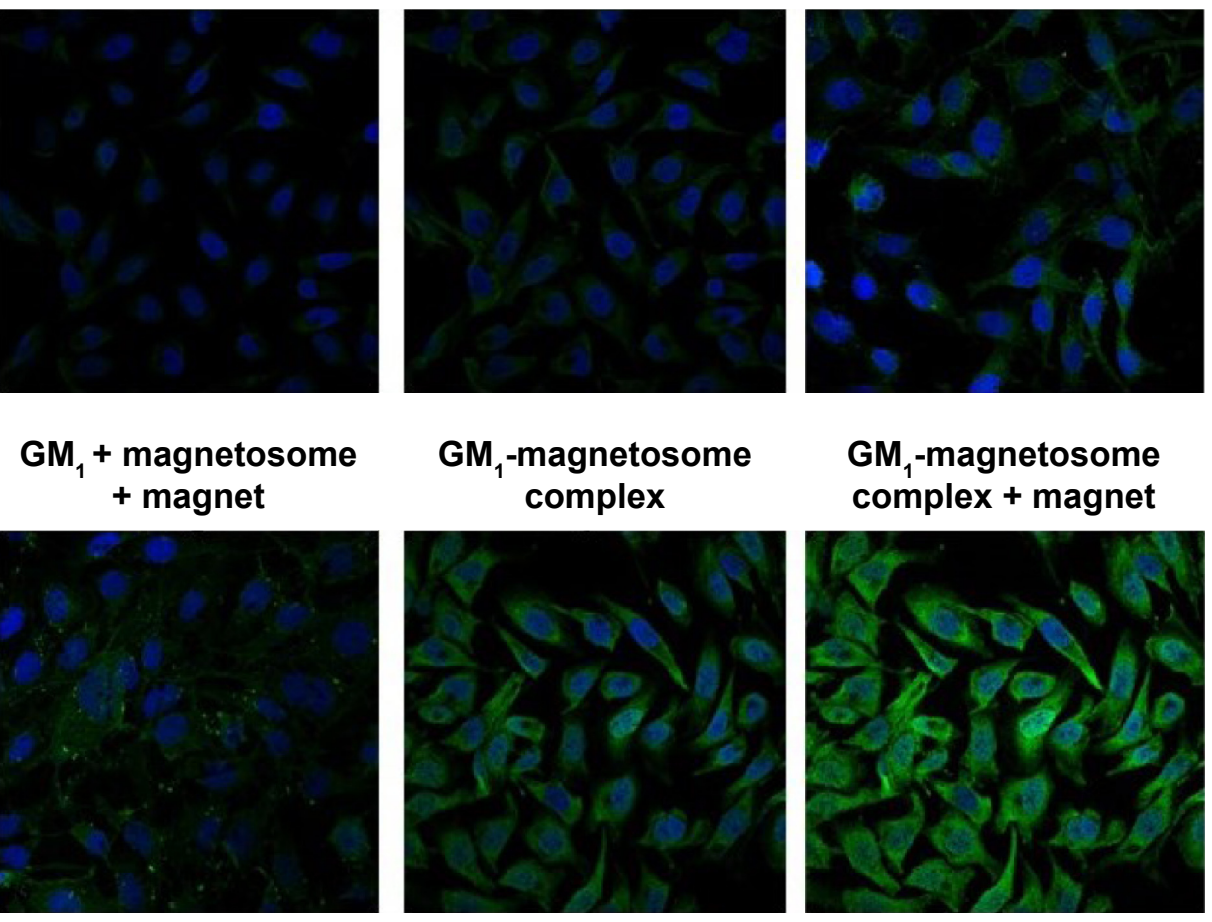

$\mathrm{GM}_{1}$-magnetosome complex + magnet
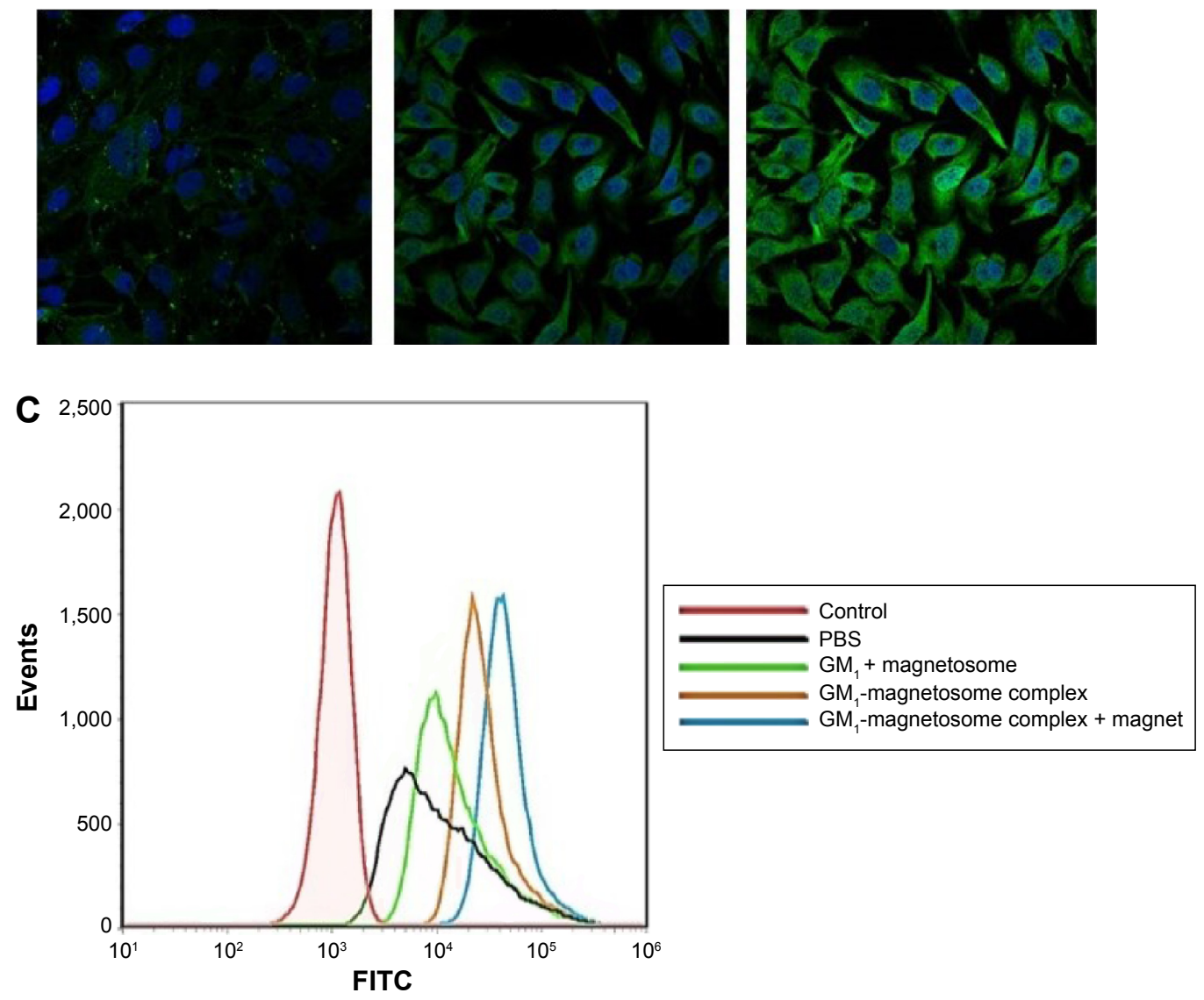

Figure 3 Uptake of GM -magnetosome complex by YTS-I cells.

Notes: YTS-I cells were treated with PBS, GM, plus magnetosomes, GM,-magnetosome complex, or GM,-magnetosome complex under magnetic field (A), as described in M\&M. Expression of GM on the cell surface was determined by confocal laser scanning microscopy (B) and flow cytometric analysis (C).

Abbreviations: FITC, fluorescein isothiocyanate; PBS, phosphate-buffered saline; M\&M, materials and methods. 
was internalized inside the cells, it was resulted from that GM, were ingested into YTS- 1 cells together with magnetosomes, but not finalizing the transportation of $\mathrm{GM}_{1}$ to the outer of the plasma membranes. These findings indicate that the uptake of $\mathrm{GM}_{1}$-magnetosome complex by YTS- 1 cells was enhanced by biocompatibility of the magnetosome membrane, and further enhanced by the presence of a magnetic field.

\section{Inhibition of $\mathrm{pEGFR}$ by $\mathrm{GM}_{3}-$ magnetosome complex}

Exogenous addition of gangliosides is a technique often used to elucidate the function of specific gangliosides as second messenger molecules or receptor modulators in cultured cells. ${ }^{7,26,27}$ For example, exogenous $\mathrm{GM}_{3}$ blocks tyrosine phosphorylation of EGFR in human epidermoid carcinoma A431 and other cell lines..$^{28,29}$ The absorption of gangliosides into cells is typically limited by their tendency to aggregate into micelles in aqueous media. ${ }^{30} \mathrm{We}$ examined the inhibitory effect of magnetosomes grafted with $\mathrm{GM}_{3}$ $\left(\mathrm{GM}_{3}\right.$-magnetosome complex) on EGFR activation. A431 cells (high EGFR expressors) are often used for studying mechanisms whereby the EGFR signal pathway is turned on or off. ${ }^{28}$ We confirmed the interaction of $\mathrm{GM}_{3}$ with EGFR using $\mathrm{GM}_{3}$-magnetosome complex. A431 cell lysate was incubated with the complex, and specific proteins binding to the complex were separated by magnetic field (Figure 4A). The EGFR protein in A431 cell lysate was clearly pulled down by $\mathrm{GM}_{3}$-magnetosome complex and confirmed by Western

\section{A}
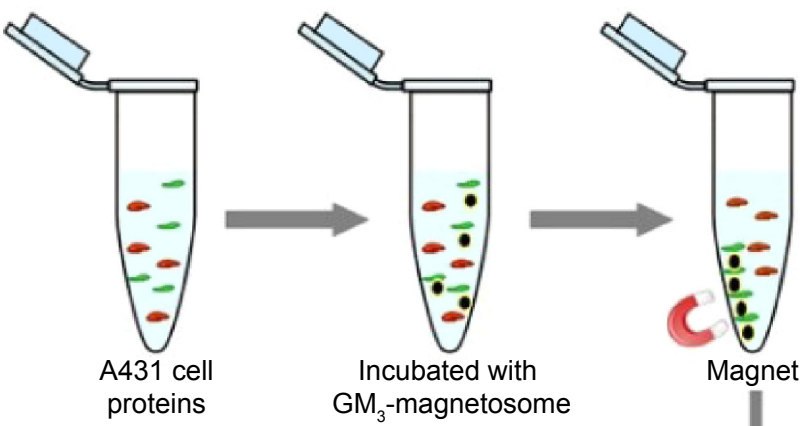
Incubated with
$\mathrm{GM}_{3}$-magnetosome
complex

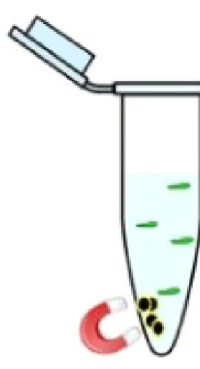
complex Magnet

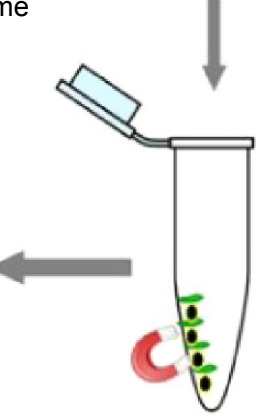

- Magnetosome

- Target proteins Non-target proteins

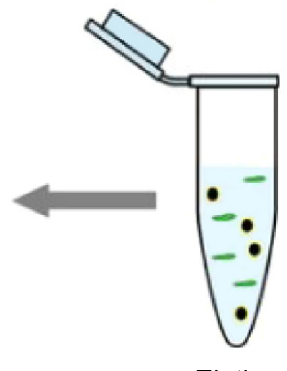

Elution

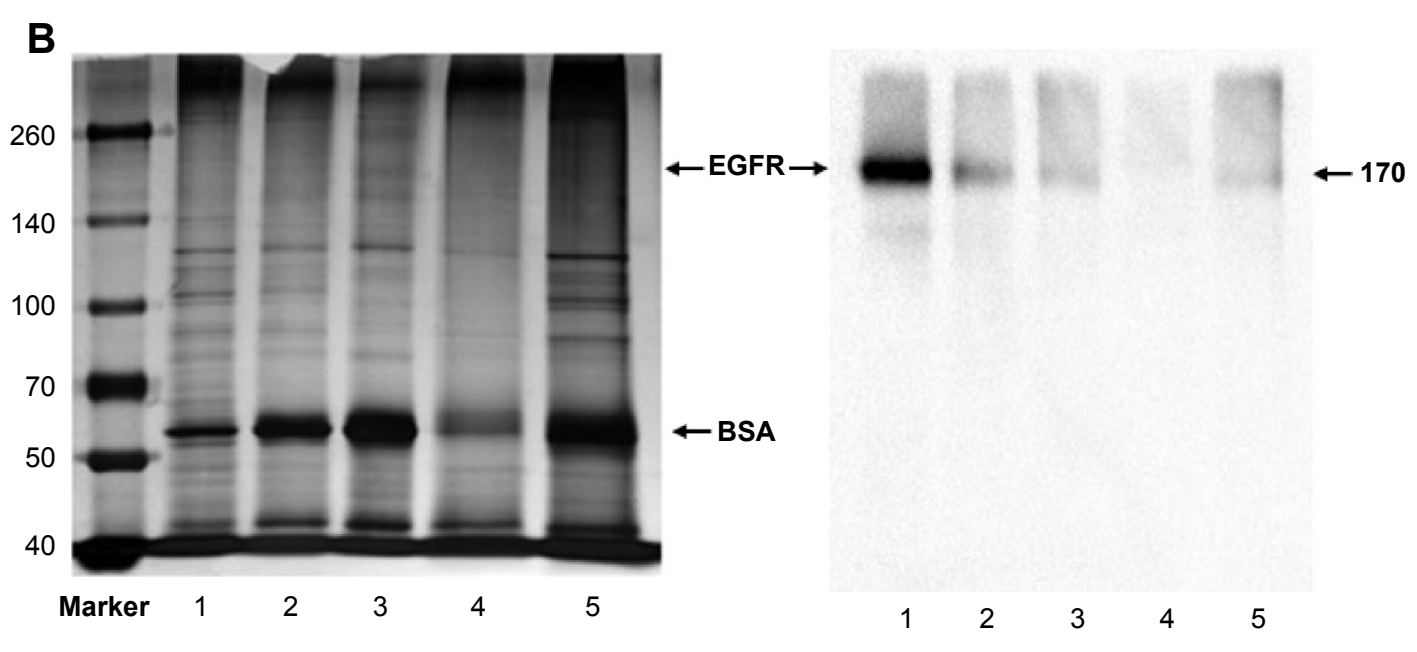

Figure 4 (Continued) 


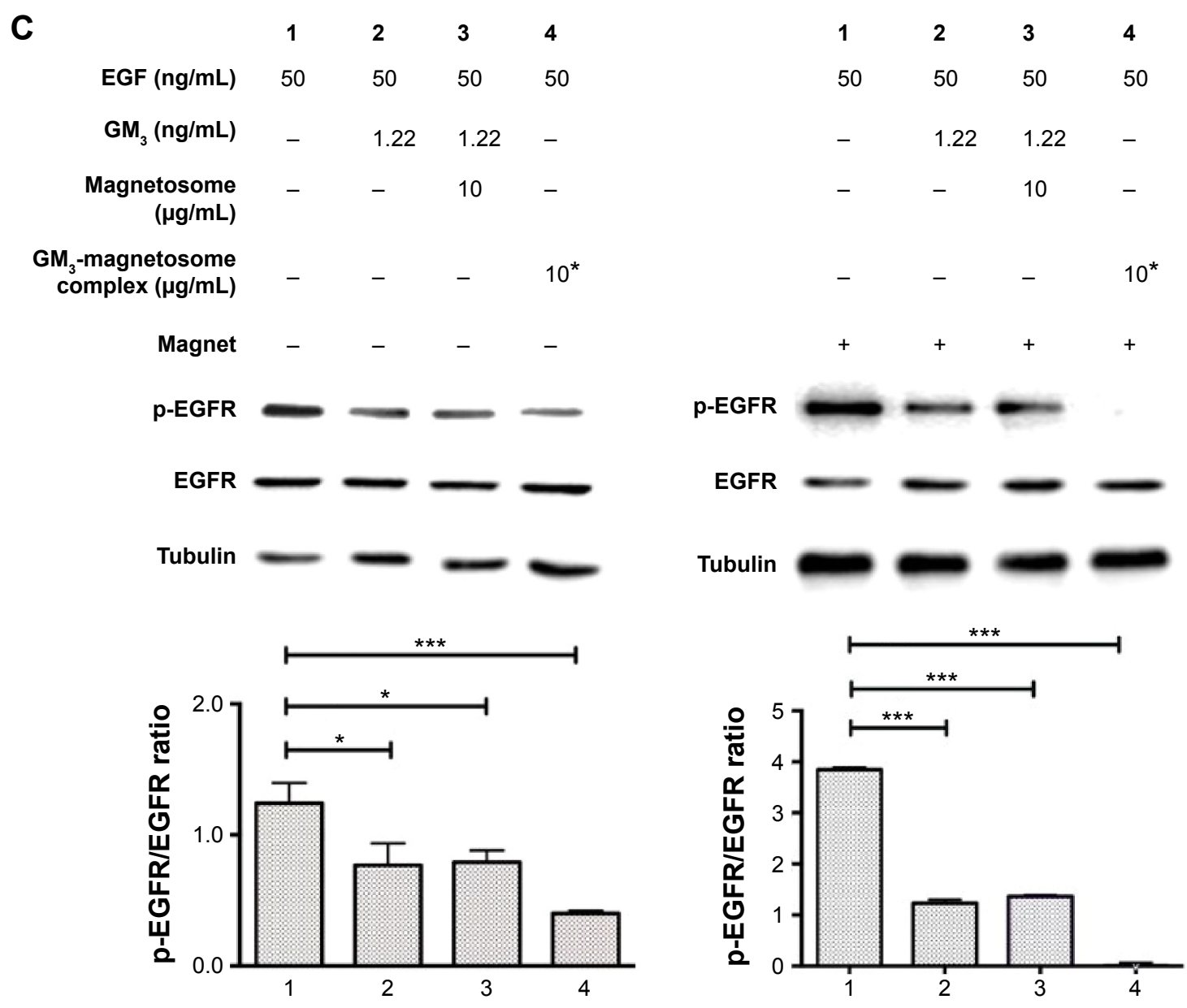

Figure 4 Effect of GM3 on EGF-induced tyrosine phosphorylation of EGFR.

Notes: (A) Technique (schematic) for evaluating interaction of $\mathrm{GM}_{3}$-magnetosomes with EGFR. (B) A43I cell lysate was incubated with PE-magnetosomes or $\mathrm{GM}_{3}$-magnetosomes, separated by a magnetic field, boiled in $50 \mu \mathrm{L}$ sample buffer, subjected to SDS-PAGE, visualized by silver staining (left), or analyzed by Western

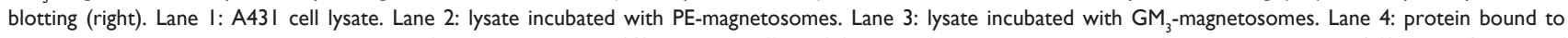
PE-magnetosomes. Lane 5: protein bound to $\mathrm{GM}_{3}$-magnetosomes. (C) Inhibitory effect of $\mathrm{GM}_{3}$ and $\mathrm{GM}_{3}$-magnetosomes on EGFR kinase activity in A43I cells. Amount of $\mathrm{GM}_{3}$ per I mg magnetosome $=0.104 \mu \mathrm{g}$. 10*: concentration of total $\mathrm{GM}_{3}$-magnetosome complex added to medium $=10 \mu \mathrm{g} / \mathrm{mL}$. EGF-induced phosphorylation of EGFR was quantified as density of phospho-EGFR divided by that of EGFR, by densitometry using Image J. Experiments were performed in triplicate, and representative Western blot results are shown (left). Data are shown as mean $\pm S D$ (right). $* P<0.05 ; * * * P<0.001$.

Abbreviations: EGF, epidermal growth factor; EGFR, epidermal growth factor receptor; p-EGFR, phosphorylated epidermal growth factor receptor; SDS-PAGE, sodium dodecyl sulfate-polyacrylamide gel electrophoresis.

blotting, whereas phosphatidylethanolamine-magnetosomes complex had no such effect (Figure 4B). EGF stimulation activated pEGFR expression as expected, and such activation was inhibited by $\mathrm{GM}_{3}$. The inhibitory effect of $\mathrm{GM}_{3}$ on pEGFR activation was significantly enhanced by complexing with magnetosomes, especially together with the presence of a magnetic field (Figure 4C).

\section{Discussion}

The potential of liposomes as biodegradable or biocompatible drug carriers for enhancing the potency of therapeutics is well established. Magnetite nanoparticles are essential components for the development of many novel biotechnological and nanotechnological applications. Among various types, bacterial magnetosomes (synthesized by magnetotactic bacteria) are of particular interest because of their paramagnetism, nano-scale size, and unique biomembrane. The natural origin and magnetic characteristics of bacterial magnetosomes have proved to be useful in a variety of biotechnological applications, including enzyme immobilization, drug delivery, and target cell separation. ${ }^{4,21}$

Glycoconjugates, located primarily in cell membranes, play essential roles in protein modification, cell-cell interaction, cell adhesion, and many other biological processes. ${ }^{31}$ In gangliosides, an important glycoconjugate family, one or more monosaccharides are glycosidically linked to a lipid moiety (ceramide). Gangliosides are usually synthesized on the membranes in the endoplasmic reticulum-Golgi pathway and delivered primarily 
to the outer leaflet of the plasma membranes. The lipid moiety is typically embedded in the cell membrane. The oligosaccharide moiety is extended (exposed) outside the bilayer membrane, and may interact simultaneously with one or more proteins or receptors. Various methods have been developed for studying protein-carbohydrate interactions, including 2-D glycoconjugate arrays on gold surfaces ${ }^{32}$ and spherical arrays of carbohydrates as represented by glycodendrimers and liposomes. ${ }^{33}$ Gangliosides (eg, $\mathrm{GM}_{1}$ ) can be incorporated in the liposome membrane, and the tendency to aggregate can be reduced by conjugation to hydrophilic polymers such as polyethylene glycol. ${ }^{34}$

We describe here a simple strategy to remove proteins from the magnetosome membrane by SDS treatment, and immobilize a ganglioside $\left(\mathrm{GM}_{1}\right.$ or $\left.\mathrm{GM}_{3}\right)$ on the magnetosome by mild ultrasonic treatment. Many evidence have shown that complexes that use magnetosomes as carriers can be easily ingested into cells through endocytosis process. ${ }^{4,35}$ In our study, gangliosides immobilized on magnetosomes was easily ingested into cells. $\mathrm{GM}_{1}$ immobilized on magnetosomes was easily taken up by cells. $\mathrm{GM}_{3}$-magnetosomes had a strong inhibitory effect on EGFR activation, also indicating increased absorption of $\mathrm{GM}_{3}$ by cells. In addition, because magnetosomes are comprised of $\mathrm{Fe}_{3} \mathrm{O}_{4}$, the magnetic field could accelerate the process that the particles entering into cells. ${ }^{35,36}$ Therefore, the effects described above were further enhanced by the presence of a magnetic field, because of the magnetic characteristics of magnetosomes. Our findings provide a basis for the application of magnetosomes in the delivery of specific gangliosides into cells, and the new strategy will be useful in studies of carbohydrate-protein interactions in vitro and in vivo.

\section{Acknowledgments}

This study was supported by Jiangsu Province Recruiting Plan for High-level, Innovative and Entrepreneurial Talents, the Fundamental Research Funds for the Central Universities (No JUSRP51319B), Jiangsu Province "Six Summit Talent" Foundation (2013-SWYY-019) and the 111 Project (No 1112-06). The authors are grateful to Dr S Anderson for English editing of the paper.

\section{Disclosure}

The authors report no conflicts of interest in this work.

\section{References}

1. Arakaki A, Nakazawa H, Nemoto M, Mori T, Matsunaga T. Formation of magnetite by bacteria and its application. $J$ R Soc Interface. 2008; 5(26):977-999.

2. Tanaka M, Okamura Y, Arakaki A, Tanaka T, Takeyama H, Matsunaga T. Origin of magnetosome membrane: proteomic analysis of magnetosome membrane and comparison with cytoplasmic membrane. Proteomics. 2006;6(19):5234-5247.
3. Dunnill P, Lilly MD. Letter: purification of enzymes using magnetic bio-affinity materials. Biotechnol Bioeng. 1974;16(7):987-990.

4. Xiang L, Bin W, Huali J, et al. Bacterial magnetic particles (BMPs)-PEI as a novel and efficient non-viral gene delivery system.J Gene Med.2007; 9(8):679-690.

5. Nakamura N, Hashimoto K, Matsunaga T. Immunoassay method for the determination of immunoglobulin $\mathrm{G}$ using bacterial magnetic particles. Anal Chem. 1991;63(3):268-272.

6. Sarikaya M. An introduction to biomimetics: a structural viewpoint Microsc Res Techn. 1994;27(5):360-375.

7. van Echten G, Sandhoff K. Ganglioside metabolism. Enzymology, Topology, and regulation. J Biol Chem. 1993;268(8):5341-5344.

8. Suk K, Kim S, Kim YH, et al. Identification of a novel human member of the DEAD box protein family. Biochim Biophys Acta. 2000; 1501(1):63-69.

9. Bremer EG, Hakomori S, Bowen-Pope DF, Raines E, Ross R. Gangliosidemediated modulation of cell growth, growth factor binding, and receptor phosphorylation. J Biol Chem. 1984;259(11):6818-6825.

10. Mutoh T, Tokuda A, Miyadai T, Hamaguchi M, Fujiki N. Ganglioside $\mathrm{GM}_{1}$ binds to the Trk protein and regulates receptor function. Proc Natl Acad Sci U S A. 1995;92(11):5087-5091.

11. Nojiri H, Stroud M, Hakomori S. A specific type of ganglioside as a modulator of insulin-dependent cell growth and insulin receptor tyrosine kinase activity. Possible association of ganglioside-induced inhibition of insulin receptor function and monocytic differentiation induction in HL-60 cells. J Biol Chem. 1991;266(7):4531-4537.

12. Aureli M, Mauri L, Ciampa MG, et al. $\mathrm{GM}_{1}$ ganglioside: past studies and future potential. Mol Neurobiol. Epub 2015 Mar 12.

13. Cuello AC. Glycosphingolipids that can regulate nerve growth and repair. Adv Pharmacol. 1990;21:1-50.

14. Tettamanti G, Riboni L. Gangliosides and modulation of the function of neural cells. Adv Lipid Res. 1993;25:235-267.

15. Polato L, Benedetti LM, Callegaro L, Couvreur P. In vitro evaluation of nanoparticle formulations containing gangliosides. J Drug Target. 1994;2(1):53-59.

16. Puryear WB, Yu X, Ramirez NP, Reinhard BM, Gummuluru S. HIV-1 incorporation of host-cell-derived glycosphingolipid $\mathrm{GM}_{3}$ allows for capture by mature dendritic cells. Proc Natl Acad Sci U S A. 2012; 109(19):7475-7480.

17. Hoshino T, Mahmood MI, Mori K, Matsuzaki K. Binding and aggregation mechanism of amyloid beta-peptides onto the $\mathrm{GM}_{1}$ ganglioside-containing lipid membrane. J Phys Chem B. 2013;117(27):8085-8094.

18. Orlando P, Cocciante G, Ippolito G, Massari P, Roberti S, Tettamanti G. The fate of tritium labeled $\mathrm{GM}_{1}$ ganglioside injected in mice. Pharmacol Res Commun. 1979;11(9):759-773.

19. Ghidoni R, Fiorilli A, Trinchera M, Venerando B, Chigorno V, Tettamanti G. Uptake, cell penetration and metabolic processing of exogenously administered $\mathrm{GM}_{1}$ ganglioside in rat brain. Neurochem Int. 1989;15(4):455-465.

20. Xiang L, Wei J, Jianbo S, Guili W, Feng G, Ying L. Purified and sterilized magnetosomes from Magnetospirillum gryphiswaldense MSR-1 were not toxic to mouse fibroblasts in vitro. Lett Appl Microbiol. 2007; 45(1):75-81.

21. Yoshino T, Hirabe H, Takahashi M, Kuhara M, Takeyama H, Matsunaga T. Magnetic cell separation using nano-sized bacterial magnetic particles with reconstructed magnetosome membrane. Biotechnol Bioeng. 2008; 101(3):470-477.

22. Wi S, Pancoska P, Keiderling TA. Predictions of protein secondary structures using factor analysis on Fourier transform infrared spectra: effect of Fourier self-deconvolution of the amide I and amide II bands. Biospectroscopy. 1998;4(2):93-106.

23. Lawrence MB, Springer TA. Leukocytes roll on a selectin at physiologic flow rates: distinction from and prerequisite for adhesion through integrins. Cell. 1991;65:859-873.

24. Satoh M, Ito A, Nojiri $\mathrm{H}$, et al. Enhanced $\mathrm{GM}_{3}$ expression, associated with decreased invasiveness, is induced by brefeldin A in bladder cancer cells. Int J Oncol. 2001;19(4):723-731. 
25. Carton I, Malinina L, Richter RP. Dynamic modulation of the glycosphingolipid content in supported lipid bilayers by glycolipid transfer protein. Biophys J. 2010;99(9):2947-2956.

26. Bremer EG, Schlessinger J, Hakomori S. Ganglioside-mediated modulation of cell growth. Specific effects of $\mathrm{GM}_{3}$ on tyrosine phosphorylation of the epidermal growth factor receptor. J Biol Chem. 1986; 261(5):2434-2440.

27. Kawamura S, Ohyama C, Watanabe R, et al. Glycolipid composition in bladder tumor: a crucial role of $\mathrm{GM}_{3}$ ganglioside in tumor invasion. Int J Cancer. 2001;94(3):343-347.

28. Yoon SJ, Nakayama K, Hikita T, Handa K, Hakomori SI. Epidermal growth factor receptor tyrosine kinase is modulated by $\mathrm{GM}_{3}$ interaction with N-linked GlcNAc termini of the receptor. Proc Natl Acad Sci US A. 2006;103(50):18987-18991.

29. Hakomori SI, Handa K. GM3 and cancer. Glycoconj J. 2015;32(1-2): $1-8$.

30. Cantu L, Del Favero E, Brocca P, Corti M. Multilevel structuring of ganglioside-containing aggregates: from simple micelles to complex biomimetic membranes. Adv Colloid Interface Sci. 2014;205:177-186.
31. Crocker PR, Feizi T. Carbohydrate recognition systems: functional triads in cell-cell interactions. Curr Opin Struct Biol. 1996;6(5):679-691.

32. Horan N, Yan L, Isobe H, Whitesides GM, Kahne D. Nonstatistical binding of a protein to clustered carbohydrates. Proc Natl Acad Sci US A. 1999; 96(21):11782-11786.

33. de La Fuente JM, Barrientos AG, Rojas TC, et al. Gold glyconanoparticles as water-soluble polyvalent models to study carbohydrate interactions. Angew Chem Int Ed Engl. 2001;40(12):2257-2261.

34. Lian T, Ho RJ. Trends and developments in liposome drug delivery systems. J Pharm Sci. 2001;90(6):667-680.

35. Lei H, Li SY, Yong Y, Zhao FM, Jie H, Jin C. Research on the structure and performance of bacterial magnetic nanoparticles. J Biomater Appl. 2008;22(5): 433-448.

36. Alphandery, Edouard, et al. Chains of magnetosomes extracted from AMB-1 magnetotactic bacteria for application in alternative magnetic field cancer therapy. ACS Nano. 2011;5(8):6279-6296. 


\section{Supplementary materials Methods}

Zeta potential and size distribution measurements.

Zetapotential ofmagnetosomes and ganglioside-magnetosome complexes were performed on a Zetasizer Nano ZS system
(Malvern, UK) equipped with a standard laser at $633 \mathrm{~nm}$. The size distribution of the formed complexes was analyzed using the above Zetasizer Nano ZS system.

Table SI Zeta potential of magnetosomes and ganglioside-magnetosome complexes

\begin{tabular}{llll}
\hline & Magnetosomes & GM $_{1}$-magnetosomes complex & GM $_{3}$-magnetosomes complex \\
\hline Zeta potential & -42.18 & -17.84 & -14.84 \\
\hline
\end{tabular}

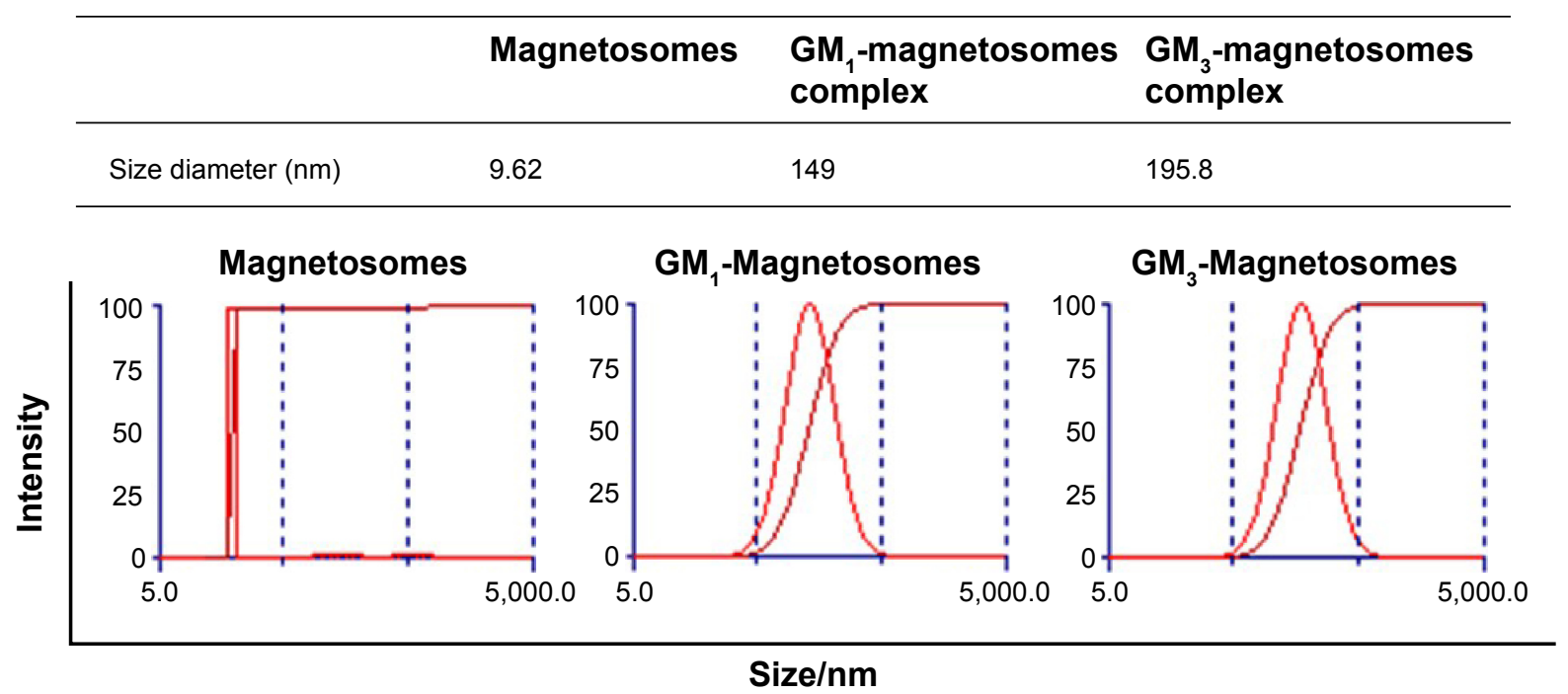

Figure SI Size distribution of magnetosomes and ganglioside-magnetosome complexes.

Table S2 Grafting efficiency of gangliosides onto magnetosomes

\begin{tabular}{|c|c|c|c|c|c|}
\hline \multirow[t]{2}{*}{$\begin{array}{l}\text { Ultrasonic bath } \\
\text { time (minutes) }\end{array}$} & \multirow[t]{2}{*}{$\begin{array}{l}\mathrm{GM}_{1} \text { or } \mathrm{GM}_{3} \text { added } \\
\text { initially, } \mathrm{Wt}(\mu \mathrm{g})\end{array}$} & \multicolumn{2}{|c|}{$\begin{array}{l}\text { GSLs grafted, } \mathbf{W g}(\mu \mathrm{g}) \\
(\text { mean } \pm \text { SD) }\end{array}$} & \multicolumn{2}{|c|}{ Grafting efficiency (\%) } \\
\hline & & $\mathbf{G M}_{1}$ & $\mathbf{G M}_{3}$ & $\mathbf{G M}_{1}$ & $\mathbf{G M}_{3}$ \\
\hline 10 & 50 & $6.2 \pm 0.4$ & $7.4 \pm 0.6$ & 12.4 & 14.8 \\
\hline 30 & 50 & $10.4 \pm 0.7$ & $11.2 \pm 0.6$ & 20.8 & 22.4 \\
\hline 60 & 50 & $10.2 \pm 0.8$ & $10.5 \pm 0.8$ & 20.4 & 21.0 \\
\hline 30 & 20 & $8.4 \pm 1.1$ & $9.4 \pm 0.4$ & 42 & 47.0 \\
\hline 30 & 100 & $11.7 \pm 1.2$ & $11.6 \pm 1.5$ & 11.7 & 11.6 \\
\hline
\end{tabular}

Notes: Grafting efficiency $(\%)=\mathrm{Wg} / \mathrm{Wt} \times 100$. Reaction system: a defined amount of ganglioside was added to $\mathrm{I} \mathrm{mL} P B S(\mathrm{pH} 7.5)$ buffer containing I $\mathrm{mg} / \mathrm{mL}$ magnetosomes.

Abbreviations: PBS, phosphate-buffered saline; GSLs, Glycosphingolipids; SD, standard deviation. 
A

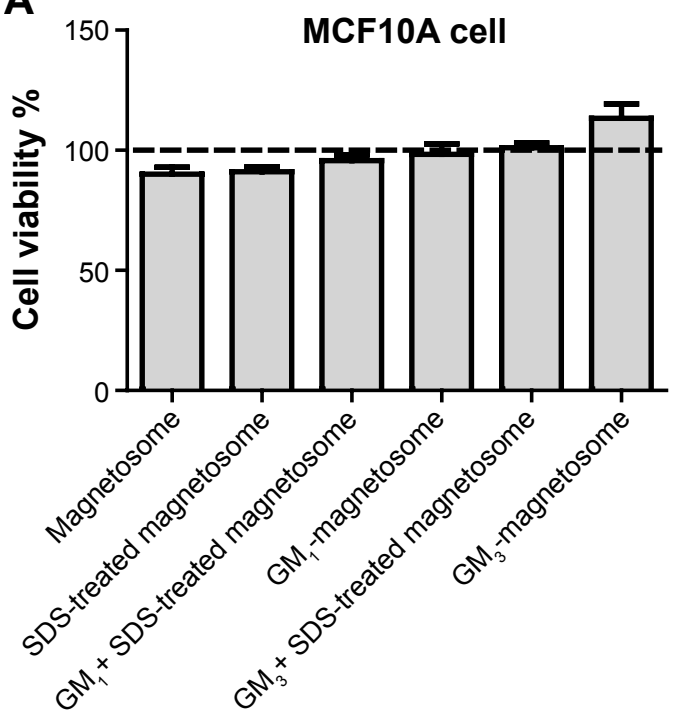

B
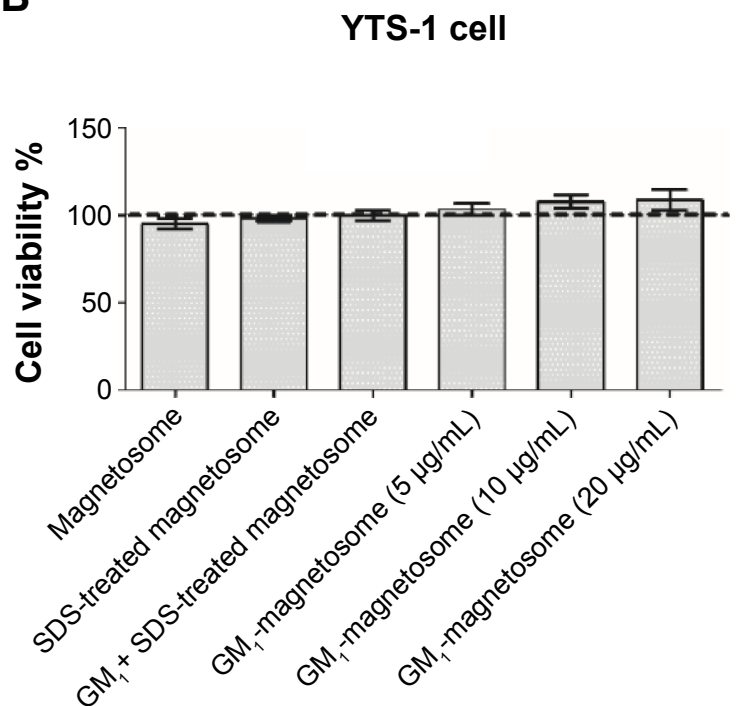

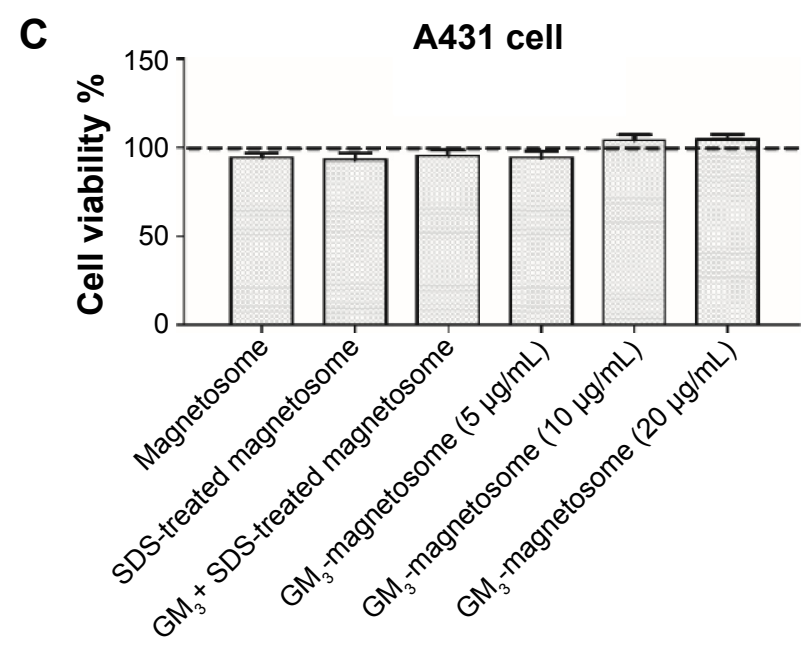

Figure S2 MTT assay of ganglioside-magnetosome complexes.

Notes: (A) Human mammary epithelial MCFIOA cells ( I $\times 10^{3}$ per well in 96-well plates) were cultured in DMEM for 48 hours. Aliquots (I0 $\left.\mu \mathrm{g} / \mathrm{mL}\right)$ of control magnetosomes,

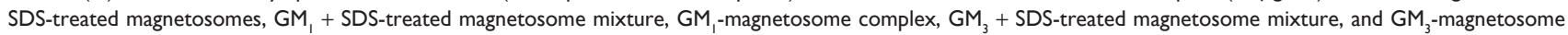
complex were added to the culture medium, and culture was continued for 24 hours. Each well was added with $20 \mu \mathrm{L}$ MTT solution and incubated 4 hours at $37^{\circ} \mathrm{C}$. The reaction was stopped by addition of $700 \mu \mathrm{L} \mathrm{DMSO}$, and absorption at $\mathrm{OD}_{595}$ was recorded immediately. Experiments were performed in triplicate, and data are shown as mean \pm SD. (B) Magnetosomes, SDS-treated magnetosomes and 5, 10, and $20 \mu \mathrm{g} / \mathrm{mL} \mathrm{GM}$-magnetosomes complex were added to YTS-I cells, respectively,and cell viability assay was performed as described above. Experiments were performed in triplicate, and data are shown as mean \pm SD. (C) Magnetosomes, SDS-treated magnetosomes and 5,10 , and $20 \mu \mathrm{g} / \mathrm{mL} \mathrm{GM}_{3}$-magnetosomes complex were added to A43I cells, respectively, and cell viability assay was performed as described above. Experiments were performed in triplicate, and data are shown as mean \pm SD.

Abbreviations: DMEM, Dulbecco's Modified Eagle's Medium; DMSO, dimethyl sulfoxide; MTT, 3-(4,5-dimethylthiazol-2-yl)-2,5-diphenyltetrazolium bromide; SDS, sodium dodecyl sulfate; SD, standard deviation.

\section{Dovepress}

\section{Publish your work in this journal}

The International Journal of Nanomedicine is an international, peerreviewed journal focusing on the application of nanotechnology in diagnostics, therapeutics, and drug delivery systems throughout the biomedical field. This journal is indexed on PubMed Central, MedLine, CAS, SciSearch $®$, Current Contents ${ }^{\circledR} /$ Clinical Medicine,
Journal Citation Reports/Science Edition, EMBase, Scopus and the Elsevier Bibliographic databases. The manuscript management system is completely online and includes a very quick and fair peer-review system, which is all easy to use. Visit http://www.dovepress.com/ testimonials.php to read real quotes from published authors. 